\title{
THE INFLUENCE OF TRANSFORMATIONAL LEADERSHIP ON ORGANIZATIONAL COMMITMENT AND JOB SATISFACTION WITH PROCEDURAL JUSTICE AS MEDIATING VARIABLE
}

\author{
Rico Saktiawan Jang Jaya \\ rico.saktiawan@gmail.com \\ Management, Faculty of Economicsand Business, Universitas Alma Ata
}

\begin{abstract}
The purpose of this research is to test the influence of transformational leadership on organizational commitment and job satisfaction with procedural justice as mediating variable. The role of the leader is very important given the nature of the leadership taken by these leaders can exert influence on employee commitment and job satisfaction, building on the principles ofjustice. This study uses a quantitative approach using a survey method and questionnaire instruments. Sampling of this research using purposive sampling that employees who have worked at least two years and subordinate superintendentin Coal and Processing Handling Division (CPHD) PT KPC. Hypothesis testing is conducted using hierarchical regression methods to test mediation in accordance with the rules of Baron and Kenny (1986). Questionnaire data processing taken by SPSS Statistics 21. The results of this study indicate that procedural justice is partially mediates the influence of transformational leadership on organizational commitment and job satisfaction.
\end{abstract}

Keywords: Transformational Leadership, Procedural Justice, Organizational Commitment, Job Satisfaction

\begin{abstract}
Abstrak. Tujuan dari penelitian ini adalah untuk menguji pengaruh kepemimpinan transformasional pada komitmen organisasional dan kepuasan kerja dengan ke adilan procedural sebagai variabel mediasi. Peran pemimpin sangat penting mengingat sifat kepemimpinan yang dimiliki oleh para pemimpin dapat memberikan pengaruh pada komitmen dan kepuasan kerja karyawan dengan berlandaskan keadilan. Penelitian ini menggunakan pendekatan kuantitatif dengan menggunakan metode survey dan instrument kuesioner. Pengambilan sampel penelitian ini menggunakan purposive sampling yaitu karyawan yang telah bekerja paling sedikit dua tahun dan bawahan super intendent kerjadi Divisi Proses dan Penanganan Batubara (CPHD) PT KPC. Pengujian hipotesis dilakukan dengan menggunakan metode regresi hirarkis untuk menguji mediasi sesuai dengan peraturan Baron dan Kenny (1986). Pengolahan data kuesioner dilakukan dengan SPSS Statistics 21. Hasil penelitian ini menunjukkan bahwa keadilan procedural memediasi secara parsial pengaruh kepemimpinan transformasional terhadap komitmen organisasional dan kepuasan kerja.
\end{abstract}

Kata Kunci: Kepemimpinan Transformasional, Keadilan Prosedural, Komitmen Organisasional, Kepuasan Kerja

\section{INTRODUCTION}

One of the factors that determines the organization's success in achieving its goals is the leader of the organization.The existence of organization leaders is necessary to use its power in influencing employees to behave toward the achievement of the vision and mission of the organization (Bass, 1990). A leader must be able to create a vision and mission and create conducive conditions working environment to influence subordinates to behave in accordance with the desired organization.Leadership is the process whereby one individual influences other group members toward the attainment of defined group or organizational goals (Greenberg, 2011). This definition emphasizes that leadership is not just a leadership position but rather a leader's process of influencing subordinates.

Leadership can be divided into two, transformational leadership and transactional leadership. Currently, many organizations are changing transactional leadership paradigms into transformational leadership to achieve organizational goals (Bass, 1990). In addition, Bass (1990) defines transformational leadershipas a formleadershipwhen leadersbroaden and elevate the interests of their employees, when they generate awareness andacceptarice of the purposes and mission of thegroup, and when they stir their employees tolook beyond their own self-interest for thegood of the group.In Coal and Processing Handling Division, transformational 
leadership can be seen in superintendent positions. Superintendent in this division has challenge and duty to empower, train, and involve employees. Superintendent must also be able to change the nature and behavior of subordinates to work to achieve corporate goals.Superintendent in this division should be able to educate, develop, motivate, provide a positive influence, and treating employees as individuals for the employee to work more in order to achieve company goals.Superintendent in this division is also required to be regarded as a relative/friend for its employees in order to create an open atmosphere in work. The obvious form that has taken place in this division is the openness of the employee in expressing the problem to the superintendent and the superintendent openly also assisting the employee in finding the solution. In showing the charisma side, the superintendent always dressed neatly and always led the morning briefing to give direction to his employees before starting work.

The role of transformational leadership in creating satisfaction and increasing commitment must be reflected in the perceived justice of employees. The organizational justice used in this research is procedural justice. Procedural justice is people's perceptions of the fairness of the procedures used to determine the outcomes they receive (Greenberg, 2011). From this understanding it is very important for transformational leaders to implement procedures that can create a sense of justice for subordinates.Pillai et al. (1999) state that the treatment of transformational leaders will affect the process of social exchange that links between transformational leadership and procedural justice. Transformational leaders who treat their subordinates fairly will contribute to increased commitment and employee satisfaction.

Superintendents play a role in executing the policies, rules, systems, and managerial decisions made by company management. Policies, rules, systems, and decisions created must be able to be communicated by the superintendent on the basis of fair treatment for employees. Mowday et al. (1979) states that fair treatment according to the perception of members of the organization is one of the requirements to support the effectiveness of organizational operations, because the creation of a sense of justice can foster attitudes and positive behavior of employees to support the achievement of organizational goals. Through Mowday's statement, it can be seen that the role of leader and leadership takes an important part in generating fair treatment for employees.

Bushra et al. (2011) conducting research on the influence of transformational leadership on organizational commitment and job satisfaction. The study took 200 samples from three banks in Lahore. The results of this study found that transformational leadership has a positive and significant effect on job satisfaction.Rokhman and Hassan (2011) do research by titleTransformational Leadership and Work Outcomes: Organizational Justice as Mediator. This study examines the effect of transformational leadership on job satisfaction, organizational commitment, and turnover intention with procedural justice as a counselor. The study found that transformational leadership had a significant effect on procedural justice. In other words, if high employee perceptions of transformational leadership will also be high employee perceptions of procedural justice.

Starting from 2012, PT KPC management socialized the work system 12 hours and steady day. This raises the pros and cons among employees. Employees with 12-hour shifts get larger compensation packages because the burden and job responsibilities are heavier.Steady day employees get no additional compensation but their facilities are better because they are inside the office. The gap in the compensation package and work facility becomes the problem between the 12-hour shift employees and the steady day employees.Employees who object to a 12 hour work policy or steady day choose to leave the company. Employees who survive but object to the 12 hour program or steady day feel uncomfortable in their work and do not get job satisfaction.In response to the case, role of superintendent transformational leadership of each division is needed to create ways or procedures in the delivery of this policy in order to create a sense of fairness among employees that will impact on employee commitment and satisfaction.

Superintendent of each division in PT 
KPC must be able to change its employees and work environment so that the difference of work system 12 hours and steady day become effective and efficient. They are also required to hear complaints of their employees and help find a solution. Fair treatment in work must also be applied superintendent so that policies that have been made can be considered fair. In addition, they must also be a figure who can be an example for their employees in running the system work 12 hours and steady day this. So employees will feel the process and fair procedures of their superintendent and will impact on increasing commitment and employee satisfaction to the company.

\section{LITERATURE REVIEW}

\section{Transformational Leadership}

Burns (1978) defines transformational leadership as a set of specific behaviors of a process in which leaders and followers mutually enhance to higher levels of morality and motivation.Extend Burns's initial theory, Bass (1990) defines transformational leadership as a form leadership when leaders broaden and elevate the interests of their employees, when they generate awareness and acceptarice of the purposes and mission of the group, and when they stir their employees to look beyond their own self-interest for the good of the group. Transformational leaders inspire their subordinates to set aside their personal interests for the good of the organization and are able to have tremendous influence on their subordinates. Transformational leaders also use the attitude of supporting employees, providing vision explanations, cultivating expectations, encouraging employees to innovate, considering individuals and broadening communication.

Bass and Avolio (1993) argue that transformational leadership has four dimensions known as The Four I's. This is the following are characteristics of The Four I dimensions:

1. Idealized Influence / Charisma.

Idealized Influence is a behavior that evokes the emotions and strong identification of subordinates towards their leaders. Idealized influence is characterized by leaders who provide vision and mission, instill pride, and gain respect and trust. Leaders prioritize the interests of the company and the interests of subordinates rather than their own interests. Leader can give the impression to his subordinates that he has the expertise in carrying out the work.

2. Inspirational Motivation

Inspirational Motivation is the leader's behavior in evoking the motivation of his subordinates. Inspirational motivation is characterized by leaders who communicate high expectations, use symbols to focus effort, and state important goals in a simple way. Leaders can inspire their subordinates by providing confidence that goals can be achieved. This will have an impact on subordinates that they feel able to do the job task and able to provide various ideas.

3. Intellectual Stimulation

Intellectual Stimulation is a behavior that increases subordinate awareness of the problem and affects subordinates to view the problem from a new perspective. Intellectual stimulation is characterized by leaders who improve intelligence, rational thinking, and solve problems cautiously. Leaders are able to cultivate new ideas, provide creative solutions to the problems faced by subordinates, and provide motivation to subordinates to seek a new approach in carrying out the work.

4. Individual Consideration

Individual Consideration is the leader's behavior in providing support, encouragement, and training for each of his subordinates. Characterized by leaders who give personal attention, treat each subordinate individually, and train and advise. The leader listens attentively to the inputs of the subordinates. In addition, leaders also pay attention, nurture, guide, and train everyone personally and personally.

\section{Procedural Justice}

Procedural justice is people's perceptions of the fairness of the procedures used to determine the outcomes they receive (Greenberg, 2011). This understanding shows that people not only pay attention to the outcomes they can get fairly but how the 
processes and procedures for sharing those outcomes. Everyone wants to be treated fairly in working in accordance with his efforts and contributions to his work.

The basic concept of procedural justice lies in the perceived justice of the procedure undertaken by the organization. Robbins and Judge (2013) argue that procedural justice is perceived fairness through the process used to determine the distribution of rewards. In order for employees to reason fairly a process, they must have control over the outcome of the decision and get a complete explanation of the outcome. For procedural justice, a leader must treat justice consistently, equally to each individual, make informed decisions accurately, and be open to employee considerations.

\section{Organizational Commitment}

Organizational commitment is the degree or degree to which the individual identifies himself with his organization and has a strong desire to best serve the interests of the organization (Robbins and Judge, 2013). Commitment to the organization will make employees more eager to remain within the organization and maintain membership within the organization.In other words, organizational commitment is an attitude that reflects employees' loyalty to the organization and the ongoing process by which organizational members express themselves to the organization as well as ongoing progress (Luthans, 2012).

Mowday et al. (1979) stated that employees who are highly committed to the organization will be more motivated to be present in the organization and strive to achieve organizational goals. Employees who have high commitment to the organization tend to be more stable and productive so that more benefit the organization.

\section{Job Satisfaction}

Job satisfaction by Locke (1969) is a happy emotional state or positive emotion derived from a job assessment or a person's work experience.Job satisfaction reflects one's feelings toward his work.Job satisfaction is a positive feeling about a job after evaluating the characteristics of the job (Robbins and Judge, 2013). Employee satisfaction relates to the value system of the company where the individual is located.

Luthans (2012) states three dimensions related to job satisfaction, that is job satisfaction is an emotional response to the work situation, job satisfaction is often determined according to how well the results achieved meet or exceed expectations, job satisfaction represents some related attitudes.

Job satisfaction is not only influenced by the work alone but also the social factors and individual employees themselves. According to Robbins and Judge (2013) the factors that affect job satisfaction are wages, working conditions, quality of supervision, coworkers, job type, job security, and opportunities to move forward. Individual factors that affect job satisfaction are the needs and interests it has, the values held, the personality traits, and the experience in the past.

\section{HYPOTHESES DEVELOPMENT}

\section{The Influence of Transformational Leadership on Organizational Commitment and Job Satisfaction}

Voon et al. (2011) conducted research on the influence of transformational leadership on job satisfaction. The study provides results that transformational leadership has a positive relationship to job satisfaction. Transformational leadership and employee job satisfaction are the two factors that form the basis for organizational success. A transformational leader is able to provide direction for his followers to achieve the desired goals of the organization. Transformational leaders tend to encourage and motivate their followers to take on more autonomy and responsibility thus increasing employee sense of accomplishment and satisfaction with their work (Voon et al., 2011). Employees with high job satisfaction tend to exert more effort in doing their work and prioritizing the interests of the organization.

Rehman et al. (2012) conducted research on the influence of transformational leadership on organizational commitment. Their results show that the influence of transformational leadership is great on organizational commitment. Each dimension of transformational leadership positively affects organizational commitment. The 
inspirational dimensions of individual motivation and consideration have a powerful influence on organizational commitment. The transformational leader is able to develop good relationships with his subordinates and be able to motivate so that it will bring emotional attachment of employees to the organization because he feels involved in the organization.

Bushra et al. (2011) research gives result that transformational leadership has a positive and significant impact on job satisfaction and organizational commitment. By adopting transformational leadership, employees will be able to feel high satisfaction with their work. If employees are satisfied with their work, they will work better and will help the organization to succeed.Employees who work on leaders who use transformational leadership have higher levels of satisfaction. Employees will be proud to be part of the organization, finding commonalities between their own values and organizational values, and ready to accept all kinds of assignments for the smooth running of the organization. Through research Bushra et al. (2011) it can be concluded that transformational leadership has a positive effect on job satisfaction and organizational commitment.

H1: There is a positive influence of transformational leadership on organizational commitment.

$\mathrm{H} 2$ : There is a positive influence of transformational leadership on job satisfaction.

\section{The Influence of Procedural Justice on Organizational Commitment and Job Satisfaction}

Kim(2009)'s research found that employees who feel treated fairly by the company will tend to develop and maintain relationships with the company. Employees who feel that they are treated fairly by the company will hold a higher commitment, believe in the company, feel satisfaction at work, and have a togetherness in controlling the work than when they know they are being treated unfairly. The results of this study emphasize that the process, manner, and procedure of distributing fair output from the company is able to increase organizational commitment and employee job satisfaction.
The results of Al-Zu'bi (2010) research show that procedural justice directly affects employee commitment and satisfaction. The effort to build employee commitment and satisfaction is by giving fair treatment to employees.Fairly treated employees will evoke positive attitudes toward the organization, among others in the form of satisfaction and commitment. The results of this study are in accordance with the statement of Tyler and Lind (1992) that if organizational processes and procedures conducted by the organization are considered fair, then employees will be more satisfied, more willing to accept the procedure, and more likely to form a positive attitude about the organization.

H3: There is a positive influence of procedural justice on organizational commitment.

H4: There is a positive influence of procedural justice on job satisfaction.

\section{Procedural Justice as a Mediation on The Influence of Transformational Leadership on Organizational Commitment and Job Satisfaction}

Research on the relationship between leadership and organizational justice in the world has found that leadership associated with organizational justice will have an effect on individual outcomes (Pillai et al., 1999). The role of leaders in creating individual outcomes should be reflected in organizational justice. If leaders do not pay attention to justice, leadership will not be effective because followers will reject leader authority. This will certainly make employees uncomfortable in working and leaving the organization. The results of Pillai et al. (1999) have proven that when a person feels fair procedures have been used in determining the outcomes they receive, commitment to the organization and trust in leaders and organizations will increase. The results of this study have also shown that procedural fairness reinforces individual employee engagement to leaders and has a strong relationship with transformational leadership.

Rokhman and Hassan (2011) examine the influence of transformational leadership on job satisfaction, organizational commitment, and turnover intention with procedural 
justice as a mediator. The study found that transformational leadership had a significant effect on procedural justice.Procedural justice also has a significant positive effect on job satisfaction and organizational commitment. It is understandable that employees will compare whether the decision-making process, mechanisms, and consequences of this decision are fair or not.This study found no significant effect of procedural justice mediation on the relationship between transformational leadership toward turnover intention. However, the effect of procedural justice mediation is significant on transformational leadership relationships with organizational commitment and job satisfaction.

H5: There is a positive influence of transformational leadership on procedural justice.

H6: There is a positive influence of transformational leadership on organizational commitment mediated by procedural justice.

H7: There is a positive influence of transformational leadership on job satisfaction mediated by procedural justice.

\section{Research Model}

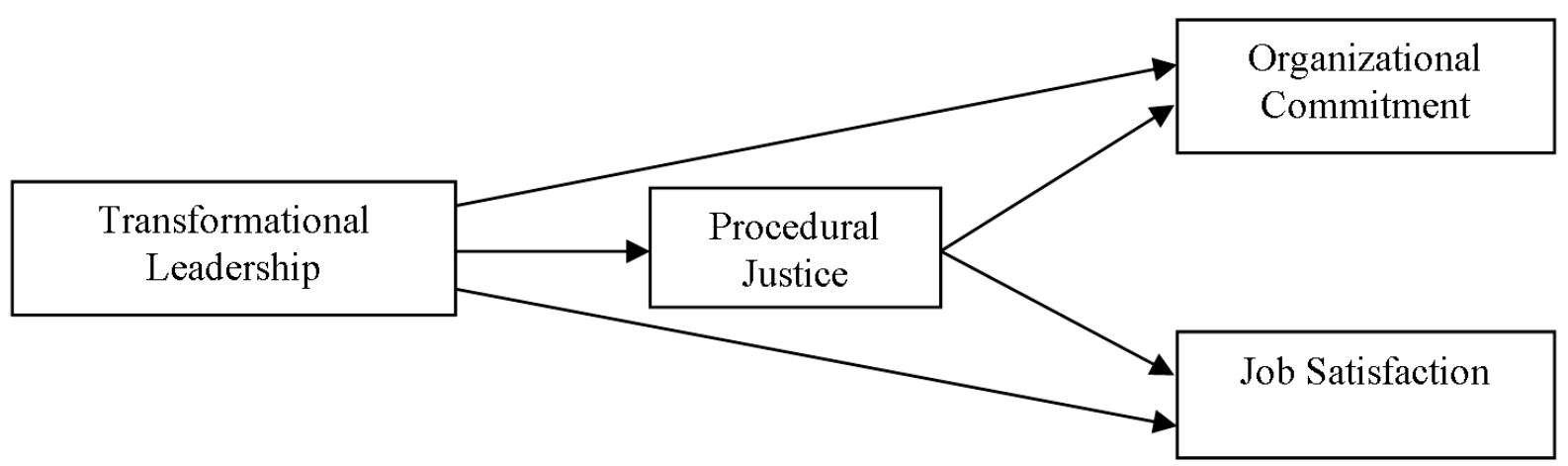

Exhibit 1. Research Model

\section{Research Design}

\section{METHODS}

This research is a quantitative research using survey method. This research is designed to test the influence of independent variables that is transformational leadership toward dependent variable that is organizational commitment and job satisfaction with procedural justice as mediation variable. The object of this research is Coal Processing and Handling Division of PT. KPC with individual as unit of analysis. Sources of data used in this study is primary data obtained directly from the results of questionnaire answers samples of employees in Coal Processing and Handling Division and secondary data coming from the company where the research was conducted.

Data collection method used in this research is survey method. Survey method is a research procedure for collecting large amount of data using question and answer format (Hair et al., 2010). The use of survey method in this study aims to obtain primary data that is the direct answer from the respondents through the distribution of questionnaires. The questionnaire used in this study is close-ended questionnaire. Horizon data collection time used is cross section atCPHDfor two weeks. Cross section data collection is the collection of data performed only once in a certain time period (Sekaran and Bougie, 2013).

The population used is all permanent employees of Coal Processing and Handling Division which amounted to 316 subjects. Hair et al. (2010) state that the sample is representative of the population. The sampling technique used to determine the respondents in this study is a non-probability sampling technique that is purposive sampling.Purposive sampling consideration in this research is an employee who has a minimum working period of two years and is a subordinate of superintendent.According to Chatman (1991), a period of two years is considered sufficient for the employee to internalize the conditions and values contained within the company. 
Roscoe (1975 in Sekaran and Bougie, 2013) statesthe rules for determining sample size, ie sample size over 30 and less than 500 are appropriate for most studies. Based on Roscoe's statement, a sample of 136 subjects can be used as a sample of this study. This rule is also supported by Hair et al. (2010) statement that research using multiple regression analysis requires a minimum sample size of 100 subjects.

\section{Hypothesis Testing}

Hypothesis testing in this study will be tested with hierarchical regression. Hierarchical regression methods were used in this study to examine the effect of mediation in the model according to the mediation test steps of Baron and Kenny (1986). In mediation testing, Baron and Kenny (1986) state the following conditions and requirements, as follows:

1. The independentvariable must be shown to influence the dependent variable. In this research is the influence of transformational leadership on organizational commitment and job satisfaction.
2. The mediator must affect thedependent variable. In this research is the influence of procedural justice on organizational commitment and job satisfaction.

3. The independent variablemust influence the mediator. In this research is the influence of transformational leadership on procedural justice.

If this condition is met, then the influence of the independent variable ( $\beta$ value) to the dependent variable during mediation should be smaller than the effect of the independent variable on the dependent variable. Perfect mediation occurs when the independent variable has no effect on the dependent variable when mediation occurs. Perfect mediation is shown by the influence of independent variables on the dependent variable when mediation becomes zero.

Based on conditions or requirement in the mediation test proposed by Baron and Kenny (1986), the hierarchical regression equation in this study is divided into four stages:

\section{First Stage}

At this stage will be tested for the condition of independent variables should affect the dependent variable.

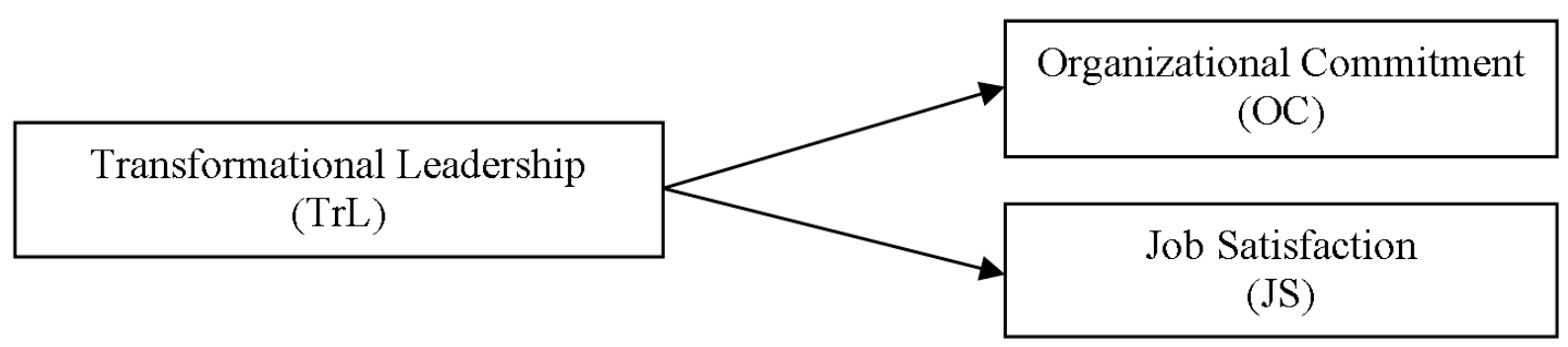

Exhibit 2. Model 2

The regression equation in model 1 are:

$O C=\alpha+\beta_{1} \operatorname{Tr} L+e$

$J S=\alpha+\beta_{2} \operatorname{Tr} L+e$

(Equation 1)

(Equation 2)
2. Second Stage

At this stage will be tested for the condition of the mediation variable should affect the dependent variable.

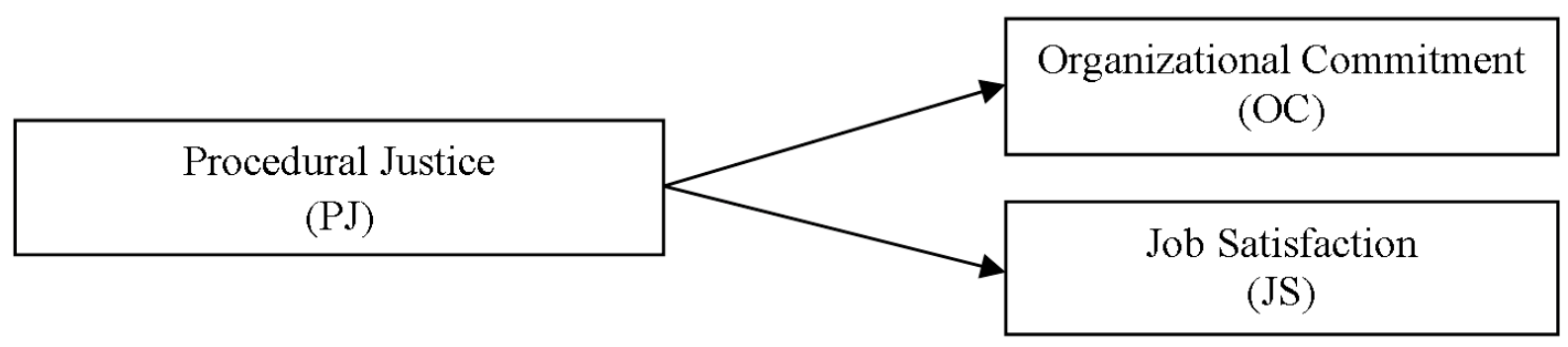

Exhibit 3. Model 3 
The regression equation in model 2 are:

$P J=\alpha+\beta_{3} O C+e$
$P J=\alpha+\beta_{4} J S+e$

(Equation 3)

(Equation 4)
3. Third Stage

At this stage will be tested for the condition of independent variables should affect the mediation variables.

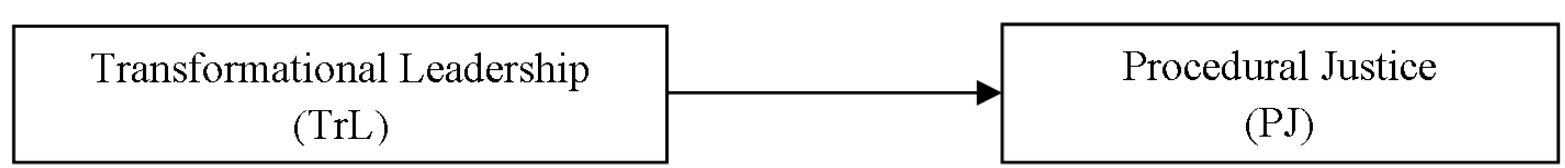

Exhibit 4. Model 4

The regression equation in model 3 is:

$P J=\alpha+\beta_{5} \operatorname{Tr} L+e($ Equation 5)
4. Fourth Stage

At this stage will be tested mediation on three variables forming the equation.

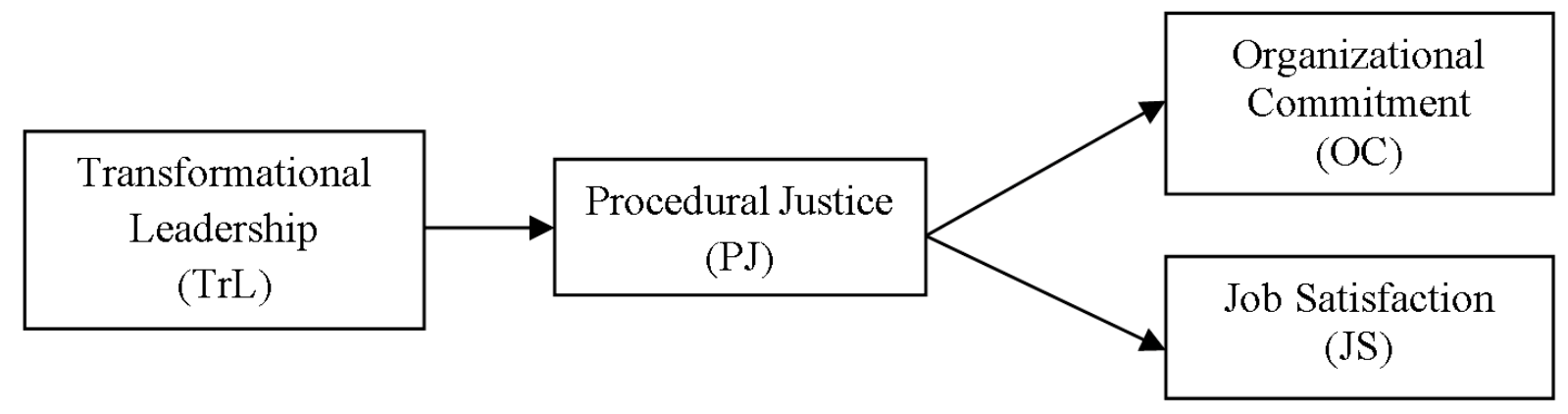

Exhibit 5. Model 5

The regression equation in model 4 are:

$O C=\alpha+\beta_{1} \operatorname{Tr} L+\beta_{2} P J+e$
$J S=\alpha+\beta_{1} \operatorname{Tr} L+\beta_{2} P J+e$

(Equation 6)

(Equation 7)

\section{RESULTS AND DISCUSSION}

Data collection techniques in this study using a questionnaire instrument. Statement items in the questionnaire amounted to 56 statements. In addition to filling out the statement items contained in the questionnaire, respondents were also asked to fill in personal data of respondents in the form of age, position, education level, and length of work. The number of distributed questionnaires was 150.

Level of questionnaire response classified high that is equal to $92,67 \%$ (139 returned questionnaire). This high level of response is due to the dissemination and filling of the questionnaire carried out during each crew shift and disseminated simultaneously to office employees. Researcher also directly involved in the distribution and collection of questionnaires assisted by the field supervisor. Researcher entered in every safety talk and morning briefings to explain the purpose of the questionnaire distribution and explanation of the contents of the questionnaire.

Validity test in this research use Pearson Correlation Product Moment analysis by correlating item score with total score (Corrected Item Total Correlation). The requirement to state the validity of each statement is that if the score of the prepared statement is positively correlated with the total score and the value of the correlation coefficient is greater than the value of the critical coefficient.

The value of critical correlation coefficient is obtained through distribution table $r$ where $r$ table in this research is 0,168 ( degree of freedom $=134(136-2)$ and $\alpha=$ $005)$. The statement in the questionnaire will be stated valid if the Corrected Item-Total Correlation value is greater than 0.168 .From the result of validity test, it is found that 20 statements that measure transformational leadership are valid, 6 statements that measure procedural justice are valid, 15 statements that measure organizational commitment are valid, 15 statements that measure job satisfaction are valid. Therefore, a total of 56 statements in the questionnaire are all stated valid. 
From 20 items a valid statement to measure transformational leadership has good category reliability with Cronbach Alpha value of 0.935 . 6 items of valid statements to measure procedural justice have category reliability acceptable with Cronbach Alpha value of 0.685 . 15 items of valid statements for measuring organizational commitment have good category reliability with Cronbach Alpha value of 0.848 . 15 items of valid statements to measure job satisfaction have good category reliability with Cronbach Alpha value of 0.848 .

Table1. Descriptive Statistics

\begin{tabular}{lcccccc}
\hline \multicolumn{1}{c}{ Variable } & Mean & Std. Dev. & $\mathbf{1}$ & $\mathbf{2}$ & $\mathbf{3}$ & $\mathbf{4}$ \\
\hline 1. Transformational Leadership & 3,80 & 0,5922 & 1 & & & \\
2. Procedural Justice & 4,05 & 0,3109 & $0,523^{* *}$ & 1 & & \\
3. Organizational Commitment & 3,64 & 0,4936 & $0,579 * *$ & $0,423 * *$ & 1 & \\
4. Job Satisfaction & 3,67 & 0,4950 & $0,692^{* *}$ & $0,476^{* *}$ & $0,846^{* *}$ & 1 \\
\hline \multicolumn{7}{c}{ Source: Primary Data (processed) } \\
& $* *$ significant at 0.01 level & & &
\end{tabular}

Based on Table 1 it can be seen that the mean value for transformational leadership is 3.80; The mean value of procedural justice of 4.05; The mean value of organizational commitment of 3.64; And the mean value of job satisfaction of 3.67. The standard deviation is used to see the variation of the value of each data against the mean value. The greater the value of the standard deviation, the greater the distance of the value of each data to the average value. The variables of transformational leadership, organizational commitment, and job satisfaction have a standard deviation value greater than the average value of their deviation standard indicating that each answer varies differently from one another while the procedural justice variable has a standard deviation value less than the standard average value The deviation that indicates that each answer is not so varied between one another.

Correlation test aims to determine the relationship between two variables (Sekaran and Bougie, 2013). If correlation coefficient positive then both variables have direct relationship. Conversely, if the negative correlation coefficient then the two variables have an inverse relationship. The correlation coefficient on all variables shows a value less than 0.9. This indicates that the data are not affected by serious collinearity problems (Hair et al., 2010).

Table2. Hierarchical Regression Test Results

\begin{tabular}{|c|c|c|c|c|c|c|c|c|}
\hline & \multicolumn{2}{|c|}{ Model 1} & \multicolumn{2}{|c|}{ Model 2} & \multicolumn{2}{|c|}{ Model 3} & \multicolumn{2}{|c|}{ Model 4} \\
\hline & \multicolumn{2}{|c|}{$\begin{array}{l}\text { Transformational } \\
\text { Leadership }\end{array}$} & \multicolumn{2}{|c|}{$\begin{array}{l}\text { Procedural } \\
\text { Justice }\end{array}$} & \multicolumn{2}{|c|}{$\begin{array}{l}\text { Transformational } \\
\text { Leadership }\end{array}$} & \multicolumn{2}{|c|}{$\begin{array}{c}\text { Transformational } \\
\text { Leadership }+ \\
\text { Procedural Justice }\end{array}$} \\
\hline & $\beta$ & $t$ & $\beta$ & $t$ & $\beta$ & $t$ & $\beta$ & $t$ \\
\hline $\begin{array}{c}\text { Mediating } \\
\text { Variable } \\
\text { Procedural Justice }\end{array}$ & - & - & - & - & 0,523 & $\begin{array}{c}7,100 \\
(0,000)\end{array}$ & & \\
\hline $\begin{array}{l}\text { Dependent } \\
\text { Variable } \\
\text { Organizational }\end{array}$ & 0,579 & $\begin{array}{c}8,228 \\
(0,000)\end{array}$ & 0,423 & $\begin{array}{c}5,407 \\
(0,000)\end{array}$ & - & - & 0,493 & $\begin{array}{c}6,035 \\
(0,000)\end{array}$ \\
\hline Commitment & & & & & & & 0,166 & $\begin{array}{c}2,027 \\
(0,045)\end{array}$ \\
\hline $\mathbf{R}^{2}$ & & 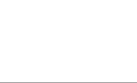 & & 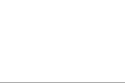 & & - & & $\begin{array}{l}56 \\
\%)\end{array}$ \\
\hline
\end{tabular}




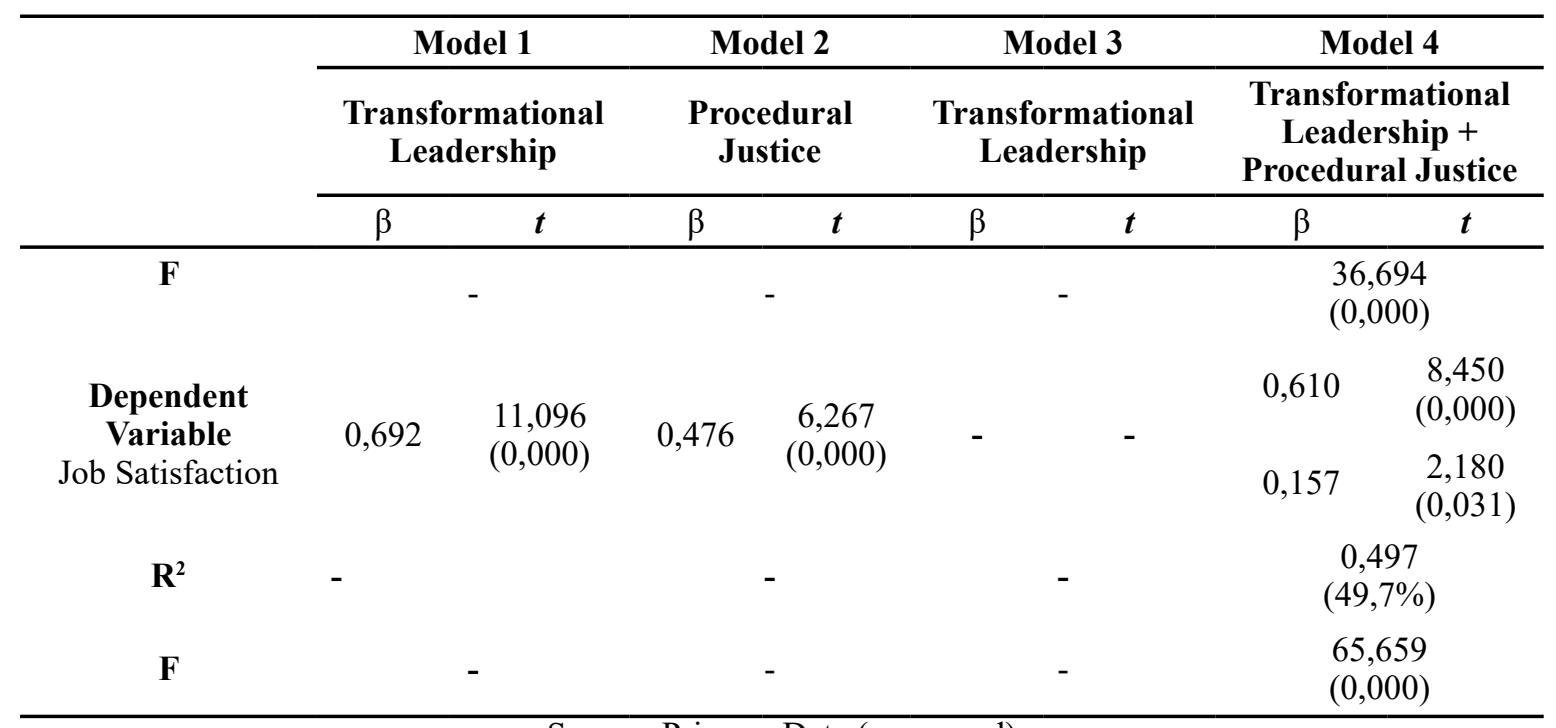

Source: Primary Data (processed)

\section{Hypothesis 1 and 2 Test Results}

From the results of testing on hypotheses 1 and 2 in this research proved that transformational leadership have positive influence on organizational commitment $(\beta$ $=0,483 ; \mathrm{t}=8,228 ; \mathrm{p}$ value $=0,000)$ andjob satisfaction $(\beta=0,578 ; \mathrm{t}=11,096 ; \mathrm{p}$ value $=$ $0,000)$. This is in accordance with Rehman et al.(2012) statementthat transformational leaders can increase the commitment and level of satisfaction of their subordinates. The results of this study in accordance with the findings of Bushra et al. (2011) research that transformational leadership has a positive and significant influence on job satisfaction and organizational commitment. Leaders who adopt transformational leadership will make employees able to feel high satisfaction with their work. Transformational leaders who encourage employees to think innovatively, spend time teaching and training employees, considering the personal feelings of employees before applying decisions, helping employees to develop strengths will increase the level of emotional attachment of employees with the organization.

According to the program from Top Management PT KPC, superintendent in Coal and Processing Handling Division will go down directly to his subordinates during working hours. The purpose of this program is that the superintendent can directly guide, teach, motivate, empower, and listen to complaints of problems from subordinates.Superintendent should also open briefings every morning early work and provide direction to subordinates before starting work. In addition, superintendent able to treat employees individually to know the advantages and disadvantages of these employees. Superintendents are required to be transformational leaders. So far, superintendent is capable of being a transformational leader. Proven from the openness of his subordinates to convey direct complaints or request assistance to the superintendent directly. By becoming a transformational leader, superintendent can improve the performance of its subordinates and make employees work beyond expectations. This is what will lead to employee satisfaction and make them commit to the company.

\section{Hypothesis 3 and 4 Test Results}

From the results of testing on hypotheses 3 and 4 in this research proved thatprocedural justicehave positive influence on organizational commitment $(\beta=0,672 ; \mathrm{t}=$ $5,407 ; p$ value $=0,000)$ andjob satisfaction $(\beta$ $=0,758 ; \mathrm{t}=6,267 ; \mathrm{p}$ value $=0,000)$. These results support Mowday et al. (1982)statement thatfair treatment according to the perception of members of the organization is one of the requirements to support the effectiveness of organizational operations, because the creation of a sense of justice can foster attitudes and positive behavior of employees to support the achievement of organizational goals. The manifestations of positive attitudes and behaviors of the members of the organization can be seen from members' commitment to organizational goals, maintaining motivation, 
job satisfaction, job engagement, and willingness to sacrifice some personal interest for the organization. These results also fit the findings in Kim (2009) research thatemployees who feel fairly treated by the company will tend to develop and maintain relationships with the company. Employees who feel that they are treated fairly by the company will hold a higher commitment, believe in the company, and feel satisfaction with their work.

Procedural justice can be seen from decisions made and submitted by superintendent not biased related employees who get 12 hours working system and employees who get the steady day work system. Before explaining the policies related to the 12 hour and steady day work system, superintendents ensures hearing the opinions of his subordinates and gathering information accurately. Superintendents utilizes safety talk and briefing in the early working hours to convey the policies that apply within the company.All decisions made are also applied consistently to employees. Employees may also refuse a superintendent's order if such an order could be harmful safety of the employee or employee feeling unable to do so. These things make employees feel high procedural justice. With high perceptions of procedural justice, employees will feel comfortable in working and feeling job satisfaction. In addition, employees who experience high procedural justice will more easily commit to the company.

\section{Hypothesis 5 Test Results}

From the results of testing on hypotheses 5 in this research proved thattransformational leadershiphave positive influence on procedural justice $(\beta=0,274 ; \mathrm{t}=7,100 ; \mathrm{p}$ value $=0,000)$. These results support Pillai et al. (1999) statement that the treatment of transformational leaders will influence the process of social exchange that connects transformational leadership and procedural justice.Transformational leaders can give their subordinates an opportunity to express their opinions about the fairness of leaders from the point of view of subordinates. Transformational leaders also give fair treatment to subordinates using the characteristics of individual considerations and intellectual stimulation. By giving individual attention, subordinates will feel the way leaders in delivering policies and directives are in line with the procedure.

Employees in Coal Processing and Handling Division are allowed to express their opinions on fair treatment provided by their superintendent. This suggests that the superintendent's role in being a transformational leader must be grounded in procedural justice. Superintendent went straight to the field to help and socialize with his subordinates so superintendent can easily convey the direction and policies in the company.This treatment will improve procedural justice perceived subordinates. Subordinates will feel treated individually and accept the ways or procedures performed by the superintendent in conveying the policy. This suggests that being a transformational leader can improve procedural justice.

\section{Hypothesis 6 and 7 Test Results}

From the results of testing on hypotheses 3 and 4 in this research proved thatprocedural justice mediates partially the positive influence of transformational leadership $(\beta=0,411$ and $p$ value $=0,000$ ) on organizational commitment and the positive influence of transformational leadership $(\beta=0,510$ and $p$ value $=0,000)$ on job satisfaction. This is appropriate with Pillai et al. (1999) statement that the role of leader in creating individual outcomes must be reflected in organizational justice.Furthermore, Pillai et al. (1999) has proven that when a person feels fair procedures have been used in determining the outcomes they receive, commitment to the organization and trust in leaders and organizations will increase.The results of this research are also supported by Rokhman and Hassan (2011) finding which examines the influence of transformational leadership on job satisfaction, organizational commitment, and turnover intention with procedural justice as a mediator.The effect of procedural justice mediation on Rokhman and Hassan (2011) research have significant relationship to transformational leadership with organizational commitment and job satisfaction.

The transformational leadership questionnaire has a mean of 3.80 so that 136 respondents perceive transformational leadership at a high level. The procedural justice questionnaire has a mean of 4.05 so that 136 respondents perceive procedural justice at a high level. The organizational 
commitment questionnaire has a mean of 3.64 so that 136 respondents perceive organizational commitment at a high level. Job satisfaction questionnaire has a mean of 3.67 so that 136 respondents feel job satisfaction at high level.

Superintendents are required to be transformational leaders by more involving subordinates in their work, guiding and training them directly, and demonstrating prestige and pride for their subordinates. All policies and treatment of the superintendent must provide a sense of fairness to their employees. Superintendents should empower, train, and provide direction to their subordinates and ensure decision procedures used for employees based on fairness.Superintendent treatment of 12-hour shift employees with steady day employees of course different. The difference of 12-hour shift employees with steady day employees lies in their working hours. The 12hour shift employee has 12 hours of working hours while the steady day employee has 8 hours of working hours. In addition, the 12-hour shift employees will get more compensation but the work is very risky while steady day employees although compensation is smaller but the facilities work very comfortable and the safety level is higher.

The superintendent's role as a transformational leader is highly demanded to deliver equitable policy and decisions for each employee and to ensure that there is no unfair treatment between a 12-hour shift employee and a steady day employee. The concrete steps undertaken by the superintendent is in training and empowering each employee, the superintendent also conveys the policies and decisions that apply in the company consistently to all employees. The purpose of this treatment is so that employees feel treated as individuals and to accept the policies conveyed by the superintendent with a sense of fairness. Utilization of safety talk and morning briefings are also used by superintendent to convey their policies and provide direction to employees. Employees will feel energized at work, feel an emotional attachment to the company, and will strive to do work beyond expectation. This shows that through procedural justice, transformational leaders can increase employee satisfaction and commitment to the company.

\section{CONCLUSION}

This research was conducted to examine the influence of transformational leadership on organizational commitment and job satisfaction with procedural justice as a mediating variable. The location chosen in this research is PT KPC Coal and Processing Handling Division in Sangatta. Sampling is done by purposive sampling, that is sampling method with consideration of employees who have been working for at least two years and is subordinate superintendent. Primary data sources in this study were obtained through questionnaires distributed to 150 respondents. Hypothesis testing is done by using hierarchical regression according to mediation test rules from Baron and Kenny (1986).

Based on the results of data processing, there is a positive influence of transformational leadership on organizational commitment and job satisfaction. Improvements in transformational leadership will have an impact on increasing organizational commitment and job satisfaction. The study also found that procedural justice mediates partially the influence of transformational leadership on organizational commitment and job satisfaction. The behavior of a transformational leader will create a social exchange that is related to the procedural justice dimension and will affect the organizational commitment and job satisfaction of its subordinates.

The company needs to maximize the performance of the superintendent to become a transformational leader based on the principle of procedural justice. By becoming transformational leaders, superintendents can be good figures for their subordinates and enhance good relationships between superiors and subordinates. If the relationship between superintendent and subordinate is good and strong then it is easy for superintendent to provide direct training to subordinates, guide, and control the company performance. Fair decision delivery will also strengthen the social relationship between superintendent and subordinate. In addition to impact on individual employees, this will certainly support the effectiveness of company performance. 


\section{REFERENCES}

Al-Zu'bi, H. A. (2010). A Study of Relationship between Organizational Justice and Job Satisfaction. International Journal of Business and Management, 5 (12), 102-109.

Bakhsi, A.; Kumar, K.; Rani, E. (2009). Organizational Justice Perceptions as Predictor of Job Satisfaction and Organization Commitment. International Journal of Business and Management, 4 (9), 145-154.

Baron, R. M. and Kenny, D. A. (1986). The Moderator-Mediator Variable Distinction in Social Psychological Research: Conceptual, Strategic, and Statistical Considerations. Journal of Personality and Social Psychology, 51 (6), 1173-1182.

Bass, B. M. (1990). From Transactional to Transformational Leadership: Learning to Share the Vision. Organizational Dynamics, 19-31.

Bass, B. M. (1999). Two Decades of Research and Development on Transformational Leadership. European Journal of Work \& Organizational Psychology, 8(1), 9-32.

Bass, B. And Avolio, B. (1993). Transformational Leadership and Organizational Culture. Public Administration Quartely, 17, 112-121.

Burns, J.M. (1978). Leadership. New York: Harper \& Row.

Bushra, F.; Usman, A.; Naveed, A. (2011). Effect of Transformational Leadership on Employees' Job Satisfaction and Organizational Commitment in Banking Sector of Lahore (Pakistan). International Journal of Business and Social Science, 2 (18), 261-267.

Chatman, J. (1991). Matching People and Organizations: Selection and Socialization in Public Accounting Firms. Administrative Science Quarterly, 36 (3), 459-484.

Fatt, C. K.; Knin, E. W. and Heng, T. N. (2010). The Impact of Organizational Justice on Employees' Job Satisfaction: The Malaysian Companies Perspectives. American Journal of Economics and Business Administration, 2 (1), 56-63.

Greenberg, J. (1990). Organizational Justice: Yesterday. Today and Tommorow. Journal of Management, 16 (2), 399-432.

Greenberg, J. (2011). Behavior in Organization, $10^{\text {th }}$ edition. London: Pearson Education.

Hair, J. F.; Black, W. C.; Babin J.; Anderson, R. E. (2010). Multivariate data Analysis, $7^{\text {th }}$ edition. USA.

Kim, H. (2009). "Integrating Organizational Justice into the Relationship Management Theory".All Academics Research.Available at http://www.allacademic.com/,accessed on 20 December 2012.

Locke, E. A. (1969). What is Job Satisfaction ?.Organizational Behavior and Human Performance, 4 (4), 309-336.

Luthans, F. (2012). Perilaku Organisasi, Edisi 10. Yogyakarta: Penerbit Andi.

Meyer, J. P. and Allen, N. J. (1991). A Three-Component Conceptualization of Organizational Commitment. Human Resource Management Review, 10, 61-69.

Mowday, R.T.; Porter, L.W.; and Steers, R.M. (1979). The Measurement of Organizational Commitment. Journal of Vocational Behavior, 14, 224-247.

Mowday, R.T.; Porter, L.W.; Steers, R.M. (1982). Employee OrganizationLingkages: The 
Psychology of Commitment, Absenteeism and Turnover.San Diego: Academic Press Inc.

Niehoff, B.P., and Moorman, R.H. (1993). Justice as a Mediator of the Relationship between Methods of Monitoring and Organizational Citizenship Behavior. Academy of Management Journal, 36 (3), 527-556.

Pillai, R.; Scandura, T. A.; Williams, E. A. (1999). Leadership and Organizational Justice: Similarities and Differences across Cultures. Journal of International Business Studies, 30 (4), 763 - 779.

Rehman, S. U.; Shareef, A.; Mahmood, A.; Ishaque, A. (2012). Perceived Leadership Style and Organizational Commitment. Interdisciplinary Journal of Contemporary Research in Business, 4 (1), 616-626.

Robbins, S. P. and Judge, T. A. (2013). Organizational Behavior, $15^{\text {th }}$ edition. United States Edition, Pearson Education.

Rokhman, W. (2011). Organizational Justice as a Mediator for Transformational Leadership and Work Outcomes. Jurnal Siasat Bisnis. 15 (2), 197-221.

Rokhman, W.and Hassan, A. (2012). Transformational Leadership and Work Outcomes: Organizational Justice as Mediator. World Review of Business Research, 2 (4), 164-171.

Sekaran, U. and Bougie, R. (2013). Research Methods for Businees - A Skill Building Approach, $6^{\text {th }}$ edition. UK : John Wiley $\&$ Sons.

Shah, J. (2007). Organizational Culture and Job Satisfaction: An Empirical study of R\&D Organization, Available at http://ssrn.com/abstract=1293922, accessed on 09 September 2012.

Tyler, T.R. and Lind, E.A. (1992).A Relational Model of Authority in Groups.Advances in Experimental Social Psychology, 25, 115 - 191.

Voon, M.L.; Lo, M.C.; Ngui, K.S.; Ayob, N.B. (2011). The Influence of Leadership Styles on Employees' Job Satisfaction in Public Sector Organizations in Malaysia. International Journal of Business, Management and Social Sciences, 2 (1), 24-32. 